\title{
Sociocultural Approach: The Development of Salt Farmers Community in Jeneponto District of South Sulawesi
}

\author{
M. Ilham Muchtar, Abbas, Hasan bin Juhanis, and Andi Satrianingsih
}

\begin{abstract}
As the smallest social unit in society, family is the first and foremost cultural environment in the context of developing various norms and behaviours that are considered important for personal, family and community life. In the context of family coaching in certain communities, the approach through sociocultural is considered very effective. The sociocultural approach in fostering family religious values is more accommodating to certain cultural values in an innovative and creative manner without losing substantial aspects of a religion. Family religious guidance in the salt farming community in Jeneponto district uses four model approaches, namely: personal approach, regional approach, traditional approach and linguistic approach. The sociocultural approach is considered effective because it touches the farmers directly without having to get rid of the values of local wisdom that they have been practicing for a long time in their daily lives. The salt farmers' community in Jeneponto district is a society from a weak economy group. Low level of education, natural factors that are not fertile, and the absence of irrigation facilities are the reasons in pursuing the profession as a salt farmer so that they have almost no other choice but to be a salt farmer.
\end{abstract}

Index Terms - Sociocultural, Approach, Salt Farmer, Community

\section{INTRODUCTION}

A person's life begins in a family setting. He grew up, grew up, and was raised in a family environment. Parents teach their children how to act. Therefore, the development of family life in its essence has always been directed at the emergence of family life as a vehicle for reconciling the religious values and values of the nation's culture. It is important to raise awareness of the importance of family norms based on a sense of responsibility, volatility, religious values, and high values of the nation's culture. Religion plays an important role in building a family. Religion that is the answer and solution to the functioning of human life is the teaching or system that governs the belief and worship of the Almighty God and the rules relating to human and human society and its environment. Therefore, a family must own and hold to a religion that it believes in to build a

Published on April 03, 2020.

M. I. Muchtar, Muhammadiyah University Makassar, Indonesia.

(e-mail: ilham_em@yahoo.com)

Abbas, Muhammadiyah University Makassar, Indonesia.

(e-mail: qmsalbirr@yahoo.co.id)

Hasan bin Juhanis, Muhammadiyah University Makassar, Indonesia. (e-mail: hasanjuhanis2@gmail.com).

Andi Satrianingsih, Muhammadiyah University Makassar, Indonesia. (e-mail: andisatrianingsih@gmail.com). successful family life in line with what the religion teaches Family Is the first and foremost element in children's character education. If a family fails to provide character education to their children, then it will be difficult for other institutions outside of parenting that parents apply to their children, as well as the school to fix it. The failure of the family in shaping the character of the child will result in the emergence of an uncharacterized. Therefore, every family should be aware that the character of the nation depends heavily on the character education of the child at home. On the other hand, the success of families in instilling values of character in children depends on the kind the socialization of norms in society so that children can live in harmony with their environment. In other words, parenting patterns also include patterns of parent-child interaction in the child's character education framework. Psychologically, a family that is part of a particular social community tends to choose privately to communicate with people outside their community. Particularly in family communities bound by limited socioeconomic conditions, it makes sense to foster interpersonal relationships. And to think they need to change the paradigm of various model approaches are more familiar with their culture (sociocultural approach) without having to get rid of the values of local wisdom that exist in the community.

\section{LITERATURE REVIEW}

\section{A. Sociocultural Theory}

Sociocultural is formed from two Latin words, socius and colere. Socius means friend or community, while Colere means processing. Colere itself comes from the English language, Culture, which is defined as all human efforts and activities in transforming and processing nature. Another theory says that culture originates from Latin, culture which means to maintain, work, and process. Meanwhile, the culture into three forms [1]: (a) ideal form, namely the form of culture as a complex of ideas, ideas, values, norms, rules, and so on. (b) The form of behaviour, namely the form of culture as a complex patterned activity of human behaviour in society. (c) The form of objects, namely the form of culture as objects of work.

Based on theory, the sociocultural approach [2] is: "The work of sociocultural theory is to explain how individual mental functioning is related to cultural, institutional, and historical context; hence, the focus of the sociocultural perspective is on the roles that participation in social interactions and culturally organized activities play in 
influencing psychological development."

The way of sociocultural theory is to explain how an individual's mentality functions in relation to cultural, institutional and historical contexts; therefore, the focus from the socio-cultural perspective is on the role to participate in social interactions and activities which will influence psychological development. Sociocultural or social cognitive theory emphasizes how one incorporates aspects of culture into their reasoning, social interaction, and self-understanding. This theory was initially better known in the world of education. There are two figures that underlie the formation of this socio-cultural learning theory, namely Piaget and Vygotsky (Jean Piaget, 1896- 1980; Lev Vygotsky, 1896-1934) [3].

Piaget argues that learning is determined because of individual initiative meaning that knowledge comes from individuals. Students interact with the social environment that is their peers compared to people who are more mature. The main determinant of learning is the individual concerned (students) while the social environment is a secondary factor. Student activeness becomes the main determinant and guarantee of success in learning, while structuring the conditions merely facilitates learning. Cognitive development is a genetic process followed by biological adaptation to the environment so that equilibration occurs. Achieving equilibration requires an adaptation process (assimilation and accommodation).

As for Vygotsky argues that a person's way of thinking can be understood by tracing the origins of his conscious actions from social interactions (activities and language used) on which his life history is based. Improvement of mental functions does not originate from the individual itself but comes from social life or the group. Social conditions as a place of dissemination and exchange of knowledge, skills and social cultural values. Children gain various knowledge and skills through active daily interactions both in the school environment and their families [4]

Acquisition of knowledge and cognitive development in accordance with the theory of sociogenesis, namely awareness of interacting with the environment, social dimensions that are primary and individual dimensions are derivative or derivative and secondary, so Vygotsky's learning theory is called the Co-Constructivism approach, meaning that one's cognitive development is actively determined by the individual himself, also determined by an active social environment as well.

According to Vygotsky the cognitive development of a child can occur through collaboration between members of one generation of the family with another. Children's development occurs in culture and continues to develop throughout his life by collaborating with others. From this perspective socio-cultural adherents argue that it is impossible to judge someone without considering the important people in their environment. The theory is associated with the coaching process in certain social communities. It can be said that, basically, any coaching process that forms cannot be separated from the action (activity) and interaction, because perception and activity go hand in hand dialogically. As learning is the process of creating meaning as a result of individual thought through interaction in a social context.
In addition, coaching material cannot be separated from activities where the source of the material is constructed and where meaning is created, as well as from the cultural community in which it is disseminated and applied. So through activities, social interactions, the creation of meaning occurs. The most dominant factor influencing sociocultural theory is the environmental factor, because according to Vygotsky, the environment has a big influence [2].

\section{B. Sociocultural Model}

The model can be interpreted as a pattern (examples, references, variations, etc.) of something that will be made or produced. So the model is sometimes identified with the approach. The model can be distinguished namely that the model is at the level of the concept, while the approach is a particular strategy used to approach an object. In the context of family coaching, especially in certain communities, a sociocultural approach is very important. Because every community as their work as well as a binder to their needs.

The sociocultural approach in fostering Islamic families, for example, is more accommodating to certain cultural values in an innovative and creative manner without losing substantial religious aspects. Besides, he stressed the importance of wisdom in understanding the culture of a particular community as an object or target of guidance (da'wah). Humans are social creatures who are given various potentials by God to develop themselves in their lives. As animal educandum, humans basically can and must be educated and can educate themselves in the process of developing themselves. Given the potential possessed by humans, it must be equipped with a fairly early education. On the other hand there are many changes in people's lives as globalization advances. This certainly has an impact on the educational process sometimes it does not go well. Social and cultural changes in society affect the world of education as a result of shifting educational paradigms such as changing the way of life, ways of learning, ways of communicating and thinking and others. This requires the wisdom and understanding of educators in developing the potential of students so that the educational process runs well.

\section{The family coaching concept}

A person's life begins in the family environment. He grew up, grew up and was educated in a family environment. Parents teach their children how they should act. Therefore, family development should always be directed at the realization of family life as a vehicle for the cultivation of religious values and noble cultural values of the nation. Need to grow and develop community awareness of the importance of family norms that are based on a sense of responsibility, volunteerism, religious values, and noble values of the nation's culture. The family as the smallest social unit in society is the first and foremost cultural environment in order to in still norms and develop various habits and behaviours that are considered important for personal, family and community life. In the norms of social teaching, family origins are formed from marriage (male and female) as confirmed by God (QS An-Nisa: 1) which means, namely [5], "And He created from her spouse and He spread from both men and many women". 
Family forms can be classified into several forms [6], namely: (a) Nuclear family a group of families consisting of fathers, mothers and children who have not separated to form a separate family, (b) Extended family is a family consisting of all people who are descended from grandfather, the same grandmother, including the descendants of each wife and husband, (c) The base family (family system) is a type of family that uses a system of inheritance of wealth in one of the oldest children, as there were many in Europe in feudal times where an older child was responsible for his younger siblings until he married, as well as for the other brother. (d) a joint family is a family consisting of people who are entitled to the results of the family's property, including brothers in each generation, and as pressure on brothers.

Family formation with a religious approach has an important role. Religion is the answer and solution to the function of human life. Therefore, a family must have and hold on to a religion that it believes so that the formation of a prosperous family can be realized in line with what is taught by the religion Family is the main tool in children's character education. If the family fails to do character education for their children, it will be difficult for other institutions outside the family (school) to fix it. Failure of the family in forming the character of a child will result in the emergence of a society that is not characterized.

Therefore, every family must have awareness that the nation's character is very dependent on children's character education at home. Conversely, the success of a family in instilling virtue values (characters) in children is very dependent on the type of parenting that parents apply to their children, as well as the socialization of the norms prevailing in society so that children can live in harmony with their environment. In other words, parenting also includes patterns of parent-child interaction in the context of children's character education.

Thus family coaching is obviously very important, but is often ignored. Correct ethics must be taught to children from childhood, so that when a child becomes an adult, he will behave well. The parents' behaviour must also be good and right as an example for their children. If a child is taught properly and correctly the family will be harmonious. And if every family teaches ethical values that are true then all humans will live side by side and peace.

\section{Salt farmers community}

The community comes from Latin community meaning: similarity then can be derived from communis which means "equal, public, shared by all or many". Community is a group social of a few organisms that share the environment. In general, a community has the same interests and habitats from one another. In a community, the individuals in it can have intentions, beliefs, resources, preferences, needs, risks and a number of other similar conditions.

Salt farmer community is a community that is not much different from other general public. But it is unique when it comes to people living in the Jeneponto coastal area. As is generally the case for residents who live in coastal areas, the typical character of families of salt farmers living in Jeneponto District tends to be harsh. Social conditions such as this are compounded by the difficulties of life experienced by the majority of the population due to infertile land and the absence of permanent employment. So to 'enter' into their lives a special approach model is needed so that they can accept it well [7]. The complexity of the family life of the salt farmer's community in Jeneponto District is interesting to be explored more deeply to find a model approach in order to make efforts for social change in the community [8].

\section{RESEARCH METHODS}

\section{A. Research type}

This research is a survey research with a qualitative approach, namely by attempting to exploit sources that aim to provide an overview of how the 'Model of the SocioCultural Approach in the Development of Religion in the Community of Salt Farmers in Jeneponto district. This type of research is based on the theory that descriptive research is research that provides a description of factual and systematic situations and events concerning the factors, traits, traits, and relationships between phenomena that are possessed to accumulate basics. Or research to explore and strengthen predictions of a phenomenon that applies on the basis of data obtained in the field.

\section{B. Focus and research location}

The main focus of this research is the community of salt farmers who live and conduct activities in Bangkala subdistrict. This sub-district was chosen because the widest area of salt ponds and the highest number of salt farmers among other sub-districts in Jeneponto district.

\section{Data sources}

The data collected in the form of primary data and secondary data. Primary data is data that is directly through interviews with people or families directly related to research. The government element in this study is Bangkala sub-district, this is to find out the number of salt farmers communities in the region. Secondary data is all forms of data obtained through the internet, magazines, journals, books, papers, articles, scientific papers and various research results related to this research. The supporting data from informants such as from religious leaders, community leaders, and so on are related to research

\section{Research instruments}

Instruments are research tools for collecting data as processing material. In addition, the instrument must also have the nature of openness so that the data obtained are of higher quality, so that an absolute study requires instruments in order to obtain the required data. The instruments used were: (a) Interviews: interviews were conducted to complete the data and information collected on other data collection methods. Interviews are used to find out things that deviate or good things from the object under study through interviews conducted in a structured manner, (b) Field Note: This instrument is also called field notes in conducting observations, namely collecting data by making direct observations of the object under study, (c) Documentation: Data obtained in the field are important documents related to the research topic, while the instruments used are recorders, cameras and field notes, in the form of descriptive notes, 
and daily notes.

\section{E. Data collecting}

Based on the theory of field research, the methods used in data collection are: (a) Observation: The observation method is used to gather information related to research, that is by observing intentionally and directly to the object under study, namely the salt farming community in Bangkala subdistrict, (b) Interview: The interview method, which is gathering information by holding questions and answers directly to informants. Interviews are conducted, always based on the following conditions: (i) The informant interviewed is first selected in accordance with the data needed, (ii) When conducting interviews conducted in accordance with the willingness of the informant, (iii) The beginning of the interview, the purpose of the interview is first explained and the objectives to be carried out by researchers, (c) Documentation: The method of documentation, namely the collection of data and information through documents, reports and written records, especially those concerning the problem under study. Related to that, the documentation that will be carried out in this study is to request various data needed from related parties in accordance with the data needed, such as religious counsellors at the Ministry of Religion, preachers, community members and others.

\section{F. Data analysis}

Considering that this research is a descriptive field research, the analysis uses qualitative methods. The technique used in data processing is qualitative i.e. the data obtained in this study are processed descriptively, critically, and interpretatively. In this study data collected from interview observations, surveys and review of documents found in the field were analyzed using inductive analysis based on the realities on the ground.

In analyzing the data collected, the following things are done: (i) Organizing data from interviews with informants, observing the object of research in the salt farmer community, (ii) Make data reduction by making abstractions about the form of coaching, as well as supporting and inhibiting factors in family coaching in the scavenger community in the location, (iii) Making data interpretation of the results of interviews and observations of informants at the study site, (iv) To check the validity of the data using triangulation techniques, the data validity checking technique utilizes something other than the data for the purposes of checking or comparing the processed data.

\section{RESUlts}

\section{A. Profile research area}

Jeneponto is the one of districts in the South Sulawesi Province, Indonesia. The district, which has the capital of Bontosunggu, has an area of $749.79 \mathrm{Km}^{2}$. with a population of 359,787 people (Census, 2017). The Regency is about 91 $\mathrm{Km}$ from Makassar geographically, located at $5^{\circ} 23^{\prime}-5^{\circ} 42$ 'South Latitude and $119^{\circ} 29^{\prime}$ - $119^{\circ} 56^{\prime}$ 'East Longitude. Its area is $749.79 \mathrm{Km}^{2}$ with West Bangkala sub-district as the most extensive sub-district that is $152.96 \mathrm{~km} 2$ or equivalent to 20.4 percent of the area of Jeneponto districts. While the smallest is Arungkeke sub-district which is $29.91 \mathrm{Km}^{2}$.
The topographical conditions of the Jeneponto districts generally have varying surfaces, in the north consisting of highlands and hills stretching from west to east with an altitude of $500-1.400$ meters above sea level (mdpl). This area is suitable for the area of horticultural crop development (fruits and vegetables). While in the middle of Jeneponto districts covers medium plain areas with an altitude of 100 - 500 meters above sea level. This soil condition is suitable for the area of plantation development and food crop agriculture. Medium in the South covers lowland areas with an altitude of $0-150$ meters above sea level. This soil condition is suitable for industrial development areas including salting industry (iodized salt) which so far has been an effort to salt the people.

The potential of waters in the Jeneponto districts is quite reliable in supporting the regional economy. The potential waters are as follows: (i) Hydrology: Several rivers that have sufficient potential for irrigation and clean water sources. Some of the river has been dammed and has been used to irrigate rice fields, such as Kelara, Tino and Poko Bulo dam, (ii) Oceanography: This region has waters and sea areas. This can be seen in the southern part stretching along the coast along $75 \mathrm{Km}$. The coastline is quite potential for the development of marine fisheries (fishing effort) karma has a variety of marine products such as skipjack fish, crabs and other marine products such as seaweed that has been sought by fishermen.

Jeneponto districts is bordered by other regions or regencies as follows: (a) North $\rightarrow$ Jeneponto borders Gowa and Takalar districts, (b) South $\rightarrow$ Jeneponto borders Flores (c) Sea West $\rightarrow$ Jeneponto borders Takalar districts, (d) East $\rightarrow$ Jeneponto borders Bantaeng districts

The boundaries of these areas can be seen on the map of the following regions:

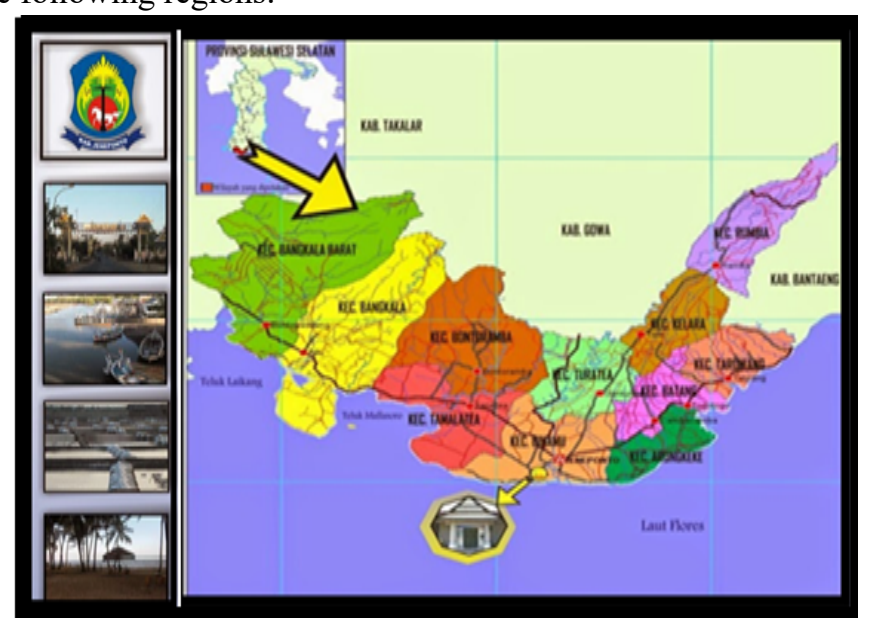

Fig. 1 Jeneponto districts Map

Jeneponto districts generally work in the agricultural sector. Many people work in this sector because the agricultural sector in Jeneponto districts is still the main employment that does not require greater sacrifice compared to other economic sectors such as industry, trade, transportation and communication and services. Another cause is the geographical condition of the area that is agrarian, so that a part of the population works in the agricultural sector, including in this case salt farming. Salt farming in Jeneponto is very potential because the sea area is directly adjacent to the Flores Sea. Until now the 
agricultural sector is still the main source of livelihood for the people of Jeneponto districts.

The local governments pay great attention to development in the agricultural sector through intensification, extensification and diversification efforts with the aim of realizing food self-sufficiency in order to improve people's lives. In addition to the agricultural sector, some residents of Jeneponto work as fishermen. Fisheries production in Jeneponto can generally be divided into marine and inland fisheries. Inland fisheries include public waters (rivers and lakes) brackish water cultivation (ponds) and freshwater aquaculture including other marine products such as seaweed. In general, the people's salt business activities in Jeneponto district are not much different from other regions on the coast of Indonesia. Land conditions in the coastal areas, basically quite good and fertile for salt ponds activities.

However, efforts to develop salt business community carried out by salt farmers are still classified as small-scale community salt businesses, because they still use traditional salt production techniques with evaporation techniques. The final product of the people's salt business activities is obtained after going through a series of stages and processes [7]. The stages and process of salt business activities in Jeneponto are determined by several factors, namely; salt production period, salting techniques, pond land conditions, community habits, and weather. From observations and interviews, the stages and the salting process, namely, the production period of the people's salt business in Jeneponto district lasts between 3 to 4 months in one cycle per year. Salting activities include 2 (two) stages, namely; (i) preparation, and (ii) salting. The harvest of salt is directly sold by farmers on the roadside, or sold to collectors who are ready to accommodate the farmers' harvests.

\section{B. Social condition of salt farmers}

The salt farmer's community in Jeneponto district is generally a group of people with weak economic conditions so that there is almost no other choice for them except to be a salt farmer. Salt farmers in Jeneponto can be divided into two types, there are indeed workers or farmers who are paid, and there are land owners or salt ponds. The number of farmer workers is greater than that of owning land. The salt farmers in the Jeneponto are not only the indigenous people of the region but there are also people who come from other regions, especially the districts which are adjacent to Jeneponto, although the numbers are small.

The sub-district region that has people's salt production is in three sub-districts, namely. Bangkala, Tamalatea and Arungkeke sub-district. In Bangkala, located in Punagaya, Bonto Marannu, Pallengu and Pantai Bahari Village. Currently in Tamalatea sub-district has two villages namely, Bonto Tangnga and Turatea Village. As for the Arungkeke district, located in Arungkeke and Borong Lamu Village. For some salt farmers, especially those who only work as fishers, the work is indeed not the only work they can do to survive, but because the work has been done by them since childhood and even has been 'inherited' by their grandfathers previous. So they throw away the sense of pride and shame to work even under the scorching heat and the results are sometimes not in accordance with their expectations. But what is important for them is how they usually pay for their families and children. During the salt harvest season, those who work as salt farmers spend a lot of their time from morning to evening around the salting site. The amount of time they use to work so that they sometimes forget their obligations to pray or other obligations.

Among the several factors that influence them to choose a job as a salt farmer are as follows: (1) Educational : The factor of low education level seems to be the basic reason so many of the salt farmers choose to continue doing the work. Hamka Bagenda (55 years), instructor of the Ministry of Religion of Jeneponto in Bangkala Sub-district said: "The average level of education of salt farmers is only Junior high school; many even only reach elementary school. Many parents do not care about their children's education, during the salt harvest they even invite the children to help them work on the pond even though it is not a holiday". (2) Economic: The economic weakness is also one of the causes of Bangkala sub-district people choosing work as salt farmers.

Hamidun (48 years), one of the salt farmers who are also the Balobboro neighborhood priest, Pallengu said: "We have lived here for decades, since our parents were old, and it seems that things continue to change. We only depend on our livelihoods on salt ponds. In the dry season, we harvest salt, but when the yield is very much like today, eh the price has dropped. So we can't do much. (3) Natural: Natural factors are the biggest reason Bangkala sub-district, especially those who become salt farmers. Most of the houses on the coast with high levels of salt water, low rainfall, and infertile soil conditions and the absence of irrigation facilities, making them like 'resigned' to the circumstances experienced. This is as said by a resident of Bangkala,

M. Supin (53 years): "This is the condition of our lives here; we depend a lot on this salt pond. And even then only 4-5 months during the dry season like this. After that we rested more, some of us chose to become farm labourers in other areas or go to sea to look for fish as a distraction ".

The same thing, the other farmers also complained namely Yunus (48 years) and Syamsuddin (42 years). These three factors are the biggest reason to make the community, especially those in Bangkala sub-district, choose a job as a salt farmer.

C. Implementation of the Sociocultural Approach in religious family development of salt farming community

The salt farmer's community in Jeneponto is generally a group of people with weak economic conditions so that there is almost no other choice for them except to be a salt farmer. Salt farmers in Jeneponto can be divided into two types, there are indeed workers or farmers who are paid, and there are land owners or salt ponds. The number of farmer workers is greater than that of owning land. The salt farmers in the Jeneponto are not only the indigenous people of the region but there are also people who come from other regions, especially the districts which are adjacent to Jeneponto, although the numbers are small.

Family religious guidance is an effort and effort made consciously of the values carried out by every family, educator or community leader with certain methods both 
personally and institutionally in order to in still the basic values of personality and knowledge that are based on religious teachings [9]. Islam religion has an important role in building a family. Religion which is the answer and solution to the function of human life is the doctrine or system that governs the system of faith (belief) and worship of God Almighty and the rules relating to the association of humans and humans and their environment [10].

Therefore, a family must have and hold on to a religion that it believes in so that the formation of a prosperous family can be realized in line with what is taught by religion. In many ways, the pattern of development of religious in the family, especially in certain communities, like the family farmer salt in Jeneponto, by using the method of approach to the sosio-cultural considered very appropriate because it will touch them directly without having to get rid of the values of local wisdom that can they have run it in their daily lives $[11,12]$.

Ustaz Muhammad Armin, (51 years) said, the coach of the Taklim Assembly to salt farmers: "In general, the salt farming community here is more happy if those who come to give religious teachings or guidance are local people, because they better understand social conditions they are also more easily understand in language.

In the context of religious life, religious formation is a deliberate attempt to foster awareness of the order of religious values so that life behaviour does not come out of religious norms. In this case, the appreciation of religion in one's life does not just believe in the faith and implementation of religious rituals, but is a continuous effort to perfect oneself in a vertical relationship to God Almighty and horizontal relations to fellow humans and the natural surroundings, so that harmonization occurs in life according to the nature of the incident. The family is the smallest social unit in society, but it is the first and foremost cultural environment in order to in still norms and develop various habits and behaviours that are considered important for people's lives [13]. For families of salt farmers in Jeneponto, religious formation for families is important; this is evidenced by the establishment of the Taklim assemblies and Kindergarden or Al -Qur'an Learning Center in almost all Mosques and Mushallas in their neighborhood. However the religious formation they received was still not optimal, generally only related to the issue of daily ritual worship.

Hamka Bagenda (55 years) said: "The guidance material that we do is still mostly on things that are ritualistic and even very basic, such as studying the Koran reading, because there are still many families of salt farmers here who are not fluent in reading the Holly Quran. While the local preachers here are still lacking, so we have to divide our time with them ". A person's life really starts in the family environment. He grew up, grew up and was educated in a family environment. Parents teach their children how they should act.

Therefore, family development should always be directed at the realization of family life as a vehicle for the cultivation of religious values and noble cultural values of the nation. Need to grow and develop community awareness of the importance of family norms that are based on a sense of responsibility, volunteerism, religious values, and noble values of the nation's culture. Thus family coaching is obviously very important, but is often ignored. True religious ethics must be taught to children from childhood, so that when a child becomes an adult, he will behave well. Of course parents' behaviour must also be good and right as an example for their children. Since a child is taught properly and correctly the family will be harmonious. And if every family teaches ethical values that are true then all humans will live side by side and peace. Family religious development especially for children in the salt farming community in Jeneponto district has not been implemented optimally. In addition to parents who have not been fully aware of the importance of religious ethics from an early age, the demands of daily life which do not contribute to the unfavourable religious character of children in the salt farming community.

According to Ustaz Muhammad Armin: because of the demands of life, generally salt farmers in Jeneponto are less concerned with fostering the religious character of their children, even many of them are no longer continuing their education after graduating elementary school, as long as it is important to be able to read and write it is enough according to they". The family is the first and main vehicle in children's character education. If the family fails to do character education for their children, it will be difficult for other institutions outside the family (school) to fix it. Failure of the family in shaping the character of children will result in the growth of society that is not characterized.

Therefore, every family must have awareness that the nation's character is very dependent on children's character education at home. Conversely, the success of a family in instilling virtue values (characters) in children is very dependent on the type of parenting that parents apply to their children, as well as the socialization of the norms prevailing in society so that children can live in harmony with their environment. In other words, parenting also includes patterns of parent-child interaction in the context of children's character education. As a religious instructor who is given the responsibility to foster the religious mentality of the target community, Ustaz Muhammad Armin and several other preachers especially those who live in Bangkala subdistrict have tried to approach various ways to the salt farming community, such as bringing missionaries from outside the Jeneponto district so that they are more enthusiastic following religious formation, the results were quite welcomed at the beginning but over time their spirits returned to the way they were before.

According to Ustaz Ahmad Syauqi, the Jeneponto Ministry of Religion instructors said: the many ways and efforts we have made, the most effective is the sociocultural approach. For example, if we invite to listen to lectures, they are usually not enthusiastic but if there is a preaching session that begins with the activity of ma'rate (congregation dhikr) then they will come together in a crowd.

The exclusive nature usually applies; they are less open to things that are still unfamiliar to their habits. So to change the paradigm of thinking they need an approach that is closer to their own culture (regional approach). Moreover, the character of salt farm families in Jeneponto in general tends to close down; they cannot be easily influenced by others $[14,15]$. 
This was confirmed by Ustaz Muhammad Azwar Kamaruddin, (44 years): one of the coaches at the Center for Islamic Studies in Jeneponto: "A custom that has been passed down by a community can not necessarily be changed, a gradual approach must be taken to pay attention to environmental factors and local culture., if this is not considered then the community may get further away." In principle, the salt farming community in Jeneponto can be invited to interact socially well, therefore the most important approach for them is not to 'injure' the culture that has been built in life they have always been. One of the most effective approaches is through community leaders or traditional leaders whom they know well (personal approach) [16,17,18]. Communities will welcome with enthusiasm such as activities such as mutual cooperation or religious activities if the people who invite them are traditional leaders or community leaders around them.

Cultural approach through linguistic approach is no less important in efforts to foster religious family of salt farmer's community in Jeneponto district. In general, in social interaction the families of the salt farmer community use the Makassar regional language in communication between their peers. So that in religious formation they are more enthusiastic if the supervisor uses the language of instruction they understand. In this case,

Hamka Bagenda (55 years), said: "People here prefer to listen to lectures if the preachers use the Makassar language because they understand better, however if there are preachers who cannot speak Makassar they also don't refuse but they are less enthusiastic maybe because they are not used to it". In theory, a community that is bound by a certain condition, or the same work and habits will tend to be more receptive to the information conveyed in the same communication language.

Therefore, in approaching certain communities, treatment needs to be done through various models so that the approach taken is more precise and effective. Observing the presentation of the results of the above research it can be said that the salt farming family community in Jeneponto district, especially those in Bangkala sub-district which is the research location, basically if a sociocultural approach done is without ignoring the local wisdoms of the people, then they are open and receptive communities, outside influence.

\section{CONCLUSION}

The salt farmer's community in Jeneponto district is a group of people with weak economic conditions so that there is almost no other choice for them except to be a salt farmer. The low level of education, natural factors that are less fertile and the absence of irrigation facilities also contribute to the reasons for supporting the profession as a salt farmer.

The most effective religious coaching in the salt farming community in Jeneponto is to use a social cultural approach (socio-cultural) because it will touch them directly without having to get rid of the values of local wisdom that they have long lived in daily life. The Sociocultural Approach applied to families of salt farming communities in Jeneponto district uses four approaches, including; personal approach, regional approach, traditional approach, and linguistic approach

\section{REFERENCES}

[1] Koentjaraningrat. (1986). Introduction to Anthropology, Jakarta: New Script.

[2] Vygotsky, L.S..(1978). Mind in society. Cambridge, MA: Harvard University Press

[3] Matusov, E., \& Hayes, R. (2000). Sociocultural critique of Piaget and Vygotsky. New Ideas in Psychology, 18(2-3), 215-239.

[4] Tudge, J., \& Scrimsher, S. Lev S. Vygotsky (2003). On education: A cultural-historical, interpersonal, and individual approach to development. In BJ Zimmerman \& DH Schunk (Eds.), Educational psychology: A century of contributions.

[5] Indonesian Ministry of Religion. (1993). Al-Qur'an and Translations, Foundation for Translation / Interpretation of the Koran, Surabaya: Surya Cipta Aksara.

[6] Goode, J. William. (1985). Family Sociology. Jakarta: Bina Aksara.

[7] Aziz, Hidayat. (2017). Strategy on Management of Salt Production in Arungkeke District, Jeneponto Regency, South Sulawesi, Bogor: IPB Press.

[8] Muchtar, M. Ilham. (2018). Socioculural Approach in the Development of Muslim Family Scavenger Communities, Tarbawi EJournal Makassar Vol. 3, No. Jan 1-Jun 2018.

[9] Djaelani, HM Solikodin. (2013). The Role of Islamic Religious Education in Family and Society, in the Scientific Journal of Widya, Vol. 1 No. July 2-August 2013.

[10] Dalila, Ulya. (2014). Religious Guidance for Taklim Assembly Women in Darussalam Islamic Boarding School in Outgrow Jatigumi, Sumber Pucung District, Malang. Cet I, UIN Maulana Malik Ibrahim Press.

[11] Miharso, Mantep. (2004). Qur'ani Family Education. Yogyakarta: Safiria Insania Press.

[12] Husni. (2012). Optimization of Family Roles in Nation Character Education, in the Ulul Albab Journal, STAIN Palopo, Vol. 14 No. January 1, 2012.

[13] Romlah, Siti. (2006). Characteristics of the Sakinah Family in Islamic Perspectives and General Education, in the Mimbar Educational Journal, No. 1 / XXV.

[14] Sukriyanto. (2002). Cultural Da'wah: The Case of Spreading Islam in Java, Faculty of Da'wah IAIN Sunan Kalijaga: Journal Da'wah No. 4 Th III January-June

[15] Soekanto, Soerjono. (1990). An Introduction to Sociology, First Edition, Jakarta: Rajawali Press.

[16] Mu'thi, Abdul Abdul. (2015). Tanfidz Decree of the 47th Muhammadiyah Congress, PP. Muhammadiyah, Gramasurya, Yogyakarta.

[17] Tafsir, Ahmad. (2007). Education in Islamic Perspective, Version. I, Bandung: PT Remaja Rosdakarya.

[18] Yakub, A., Sessu, A., Sjahruddin, H., \&, Haryono. (2020). Exploring the Nexus between Foreign Aid, Corruption and Economic Growth in ASEAN Countries Andi Yakuba*, Andi Sessub, Herman Sjahruddinc, Haryono. The International Journal of Innovation, Creativity and Change. Volume 11, Issue 2 